\title{
Development of predictive model for rate of degradation in crude oil polluted areas
}

\author{
Obi Lawrence $\mathbf{E}^{*}$ \\ Department of Civil Engineering, Imo State University, Owerri, Nigeria
}

\section{(C2017 ACCENTS}

\begin{abstract}
Environmental nuisance of pollution created by crude oil spillage had constituted great challenges to environmental experts. Notable efforts had been made to reduce the incessant pollution of the environment by crude oil. The modeling of the rate at which this crude oil waste undergoes degradation is very needful as it will help to curb the menace. In this work, twenty four experimental results were analyzed to determine the effect of crude oil concentration on bacterial growth. This is a factor considered as being responsible for the rate of degradation in crude oil polluted areas. Diverse nutrients were added in the 24 experiments at the concentrations of $0.00 \mathrm{gL}-1,125 \mathrm{gL}-1,167 \mathrm{gL}-1,417 \mathrm{gL}-1$ and $520 \mathrm{gL}-1$. Corresponding value of $25 \mathrm{~g}, 50 \mathrm{~g}, 75 \mathrm{~g}$ and $100 \mathrm{~g}$ were added as nutrients. The biomass numbers were determined weekly for a duration of six weeks. With this, a predictive model was developed to determine the number of bacteria. Bacteria are considered as being responsible for the rate of degradation of crude oil polluted areas. This prediction was found to be successful to an accuracy index of $98.5 \%$.
\end{abstract}

\section{Keywords}

Bioremediation, Biostimulation, Bioaugumentation, Crude oil, Degradation.

\section{Introduction}

Undoubtedly, nature has an inherent capacity for purification and recycling but the growth of demand placed on the environment by great amounts of anthropogenic pollution exceeds the nature's ability and assimilation capacity. The methods employed in dealing with crude oil spillage include oil plume using dispersants, or through bioremediation [1]. The threat orchestrated by oil spillage arising from oil exploration and exploitation is enormous especially in the oil producing areas located in the mangrove ecosystem. Global reserves of arable agricultural land are constantly diminishing and $25 \%$ of agricultural lands are affected by soil degradation due to man's activities. For example the recent oil spillage that occurred in 2017 in Tambiri-an Ijaw community in Yenagoa local government area of Bayelsa state of Nigeria, created agonies that ripped the inhabitants who are predominantly farmers and fishers of their farmlands and water resources. This incident and many other similar ones in the past have affected farmlands where such crops as rice, maize, cassava, yams and plantain that produce staple foods were cultivated.

*Author for correspondence
The primary outcome of petroleum contamination of soil has been its ugly effects on the water system (surface and groundwater) and the impediment created against the germination and growth of crops on such soils. It is not easy for a soil to recover its fertility after oil spillage as this depends on two principal factors which include the quantity of oil spilled and the biodegrading potential of the microbial population in the area concerned. Petroleum hydrocarbons (PHCs) make the soil barren and as such disallow crop growth and yield for a long period of time depending on the recovery capacity of the soil [2-4].

The problem of oil spillage in oil producing areas has been the reason for the restiveness and militancy prevailing in these areas. Due to the multifarious problems created by oil spillage, it becomes necessary to develop a predictive model which will help in cleaning up the affected areas and enhance the quick recovery of the disposed sites.

\subsection{Bioremediation}

Bioremediation can be defined as the use of microorganisms, plants and/or fungi in the restoration of a contaminated and polluted environment. Bioremediation is already known to microbiologists since the 1940s but it became known to a wider 
world in the 1980s. At this recent time, it was taken as a technology applied for the cleaning up of shorelines contaminated with spilled oil. Bioremediation is a process by which chemical substances are degraded by bacteria and other microorganisms. The use of these micro-organisms has been successful for the treatment of waste and wastewater in controlled systems. Reasonably, numerous researches have recently been performed to investigate the use of bioremediation for oil spill clean-up in sea-water, freshwater and terrestrial areas. This technique has been found to possess a capacity for broader applications in terrestrial and freshwater environments for treating soils and sediments polluted with oil and other substances including coastal environments impacted with oil spillage [5, $6]$.

Bioremediation technologies are normally applied to optimize the natural microbial capacity to degrade pollutants and contaminants through the provision of appropriate condition. This includes the introduction of essential nutrients that can improve the thriving of microbial population through the limitation of their growth. The best way to mitigate the effects of oil spillage is through the application of bioremediation. Bioremediation technology can be achieved by two methods namely biostimulation and bioaugumentation.

\subsubsection{Biostimulation}

This is the addition of nutrients and it is normally a practice for marine oil spillage clean-up especially when there is an existing presence population of oil degrading microbes. The occurrence of oil spillage creates the preponderance and heavy presence of carbon and this increases the growth of existing oil degrading micro-organisms.

However the growth of these oil degrading microorganisms is highly limited but remediation can bring in nitrogen and phosphorus. Through the introduction of these nutrients in the optimized quantities and concentrations, the hydrocarbon degrading microbes are stimulated and capable of attaining their maximum growth rate thereby achieving maximum rate of pollutant intake. The introduction of nitrogen as supplement nutrients improves the maximum growth rate of oil degrading microbes at a concentration of $2.0 \mathrm{mgL}-1$ [4]. Biostimulation is a proven and effective way of achieving increased hydrocarbon degradation by indigenous microbial population [7].
The trump card in the application of biostimulation is the introduction of the ideal quantity of nutrients required for maximum growth of the indigenous microorganisms and allowing this quantity to remain for a long period. Biostimulation has some limitations based on where the nutrients are applied, physical influences such as different densities, wave movements and tidal influences. Waves also have an effect on the distribution and movement of the water and its dissolved nutrients which determine the residence time of the nutrients in the oil spill affected area. The role of wave on solute movement varies inspite of the presence of tide. When wave is present, there is sharp seaward hydraulic gradient in the backwash zone and a gentle gradient landward of the area [4]. It was found out that the contact time of waves in the presence of tide increased the dispersion and washout of the nutrients in the tidal zone and residence time was approximately $75 \%$ when a wave was present with a tide as compared to a tide without waves [8].

1.1.2Bioaugumentation

This is the addition of micro-organisms that have the capacity to degrade toxic hydrocarbons with the aim of reducing pollution and its pollutants. The degradation of hydrocarbons begins with the conversion of the alkane chain or polycyclic aromatic hydrocarbon (PAH) into alcohol. Oxidation then converts the compound to an aldehyde and into an acid and eventually into water, carbondioxide and biomass. In the case of PAH, fusion occurs which ultimately leads to mineralization [9]. Bioaugumentation, defined as the addition of microbes capable of degrading hydrocarbons is applied when there are pollutants or contaminants, which are resistant to the indigenous microorganisms. Zhu et al, (2001) reported that there were several hydrocarbon degrading microorganisms, with more than two hundred species of bacteria, fungi and yeast which are capable of degrading compounds as simple as methane to compounds with more than forty carbon atoms [10].

For the fact that most environments have natural hydrocarbon degrading microbes, bioaugumentation is commonly used. Bioaugumentation has a disadvantage in application as a tool for oil spill clean-up. This is due to the fact that the addition of these non-indigenous microorganisms will often generate competition with the existing beneficial microorganisms and the non-indigenous may not survive in the environment because they are naturally adapted to it. 
Obi Lawrence E.

\subsubsection{Factors affecting bioremediation}

The conditions of contaminated site have a great effect on whether bioremediation is an appropriate method for oil spill clean-up. The success of bioremediation is dependent on physical and chemical conditions. The physical parameters include temperature, surface area of the oil, and the energy of water, while chemical parameters include oxygen and nutrient content, $\mathrm{pH}$ and the composition of the soil. Temperature affects bioremediation by altering the properties of the oil and also by influencing the oil degrading microbes.

At low temperature, the viscosity of oil is high and this condition changes the toxicity and solubility of the oil. A study showed that when crude oil was added to the presence of oil degrading microbes, they increased by two orders of magnitude at $4^{0} \mathrm{C}$, more than three orders of magnitude at $12^{\circ} \mathrm{C}$ and more than four orders magnitude at $20^{\circ} \mathrm{C}$ (Environment Canada, 2003). This explains why it takes six weeks to clean up a particular oil spill area at a warmer temperature while it takes several months to do the same task at a cooler temperature. The surface of the oil is also important because the growth of oil degrading microbes lives at the interface of water and oil. A larger surface oil area of the oil results to a larger area for the microbes which ultimately culminates into large number of microbes. Oxygen is needed for the survival of many aerobic micro-organisms which means the presence of adequate oxygen will enhance the growth of the microbes. The availability of nitrogen and phosphorus which serve as food to the microbes will boost their growth, multiplication and viability. Bioremediation is very important for the clean-up of water polluted by petroleum spill. When it is done early, it saves the lives of human beings, fishes and other aquatic animals [9].

\subsection{Crude oil}

The success of strategies for oil spill clean-up depends on the physical and chemical characteristics of the spilled oil in relation to the environment. Crude oil and other oil products differ in their rates of weathering in the environment. The changes in the physical and chemical properties of the oil have a direct bearing on oil recovery clean-up operations. These influence selection of response methods and technologies applicable for clean-up including their effectiveness and capacity, which can affect the time and cost of operations and the impacts on natural resources. Petroleum products (crude oil and fuels) vary in their volatility, flammability, water solubility, tendency to emulsify, viscosity and density. Some products are light, volatile, non-viscous and less flammable (heavy fuel oil). Spill response will differ depending on the oil type and its distinct characteristics. Safety concerns are greater and more important for light volatile flammable products than for heavier oils. The response preferences for flammable products are essentially to control the source and maintain a safe distance.

1.2.1 Presence of heavy metals in crude oil

Heavy metals can be defined as trace metals with densities greater than $5 \mathrm{mg} / \mathrm{cm}^{3}$. Many soils naturally have varying but trace amounts of heavy metals even in undisturbed environments. These amounts can be changed because many industrial processes such as smelting, burning fossil fuels, petroleum prospecting and mining, produce heavy metals which if not properly and carefully controlled end up in the soil. Any increase in these heavy metals shows that there is contamination. When the concentration of these metals such as Cadmium (Cd) exceeds certain level, they can become toxic to plants. They assume particular importance when considering bioaccumulation because there is no indication currently that most of them (with the exception of Vanadium and titanium) are used by animals in their metabolic processes. Outside the traditional toxicological relevance of these trace heavy metals, some like Nickel and Vanadium that are natural constituents of crude oil, have found use as diagnostic indices of hydrocarbon degradation and oil correlation [10].

Major Nigerian crude oil brands such as Bonny light, Forcados Blend and Qua Iboe light, have the following heavy metal contents: Vanadium (1.0ppm), Nickel (4.0 ppm), Cadmium (0.1 ppm), Copper (0.1 ppm) and lead (0.1 ppm).

\section{Methodology}

\subsection{Sources of data}

The data utilized in this research were obtained from literature (Agunwamba et al, 2004, Kogbara et al, 2008). The cells were situated at Rivers State University of Science and Technology Teaching and Research Farm at an ambient temperature of $27^{\circ} \mathrm{C}$.

\subsection{Predictive model formulation}

The development of predictive model for the rate of degradation in crude oil polluted sites led to the study of the effect of crude oil concentration on bacterial growth. Investigation using the existing exponential equation as shown in eqn 2.1 resulted in the formulation of the model;

$$
B=a t^{\beta} e^{b t^{2}}-------(1)
$$


Where $\mathrm{a}, \mathrm{b}$ and $\beta$ are model constants whose values are functions of crude oil concentration of the amount of nutrients added while $B=$ Biomass Number $t$ $=$ Time in days in which the bacterial growth die off $e=$ an exponential function

The linearization of the exponential equation (1) resulted into the linear equation;

In $B=\operatorname{In} a+\beta \operatorname{In} t+b t^{2}------(2)$

Putting equation (2) in $\mathrm{x}$ and $\mathrm{y}$ co-ordinates we have; $y=a_{0}+a_{1} x_{1}+a_{2} x_{2}-----(3)$ Where $y=\operatorname{In} B, a_{0}=\operatorname{In} a, a_{1}=\beta$ $x_{1}=$ in $t, a_{2}=b$, and $x_{2}=t^{2}$

Subjecting equation (3) to multivariate regression analysis by using the experimental data. In the process the constants $a_{0}, a_{1}$ and $x$ were determined for each of the 24 experiments performed. A multivariate regression was undertaken by plotting the constants $a, b$ and $\beta$ against the concentration ' $\mathrm{C}$ ' of the crude oil and the plotting the constant $a, b$ and $\beta$ against the amount of nutrients added $(\mathrm{N})$.

\section{Results and analysis}

\subsection{Results}

With the data collected, multivariate regression analysis was conducted by plotting the constant $a, b$ and $\beta$ against $C$ (i.e. concentration of crude oil) and through this, the following equations were obtained

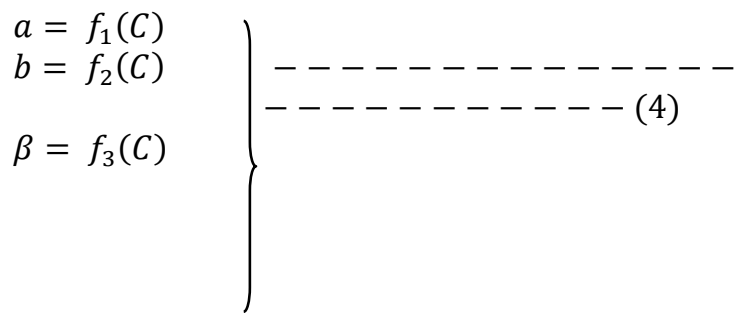

In the same manner, a plot $a, b$ and $\beta$ against $\mathrm{N}$ (i.e amount of nutrients) added with the following results;

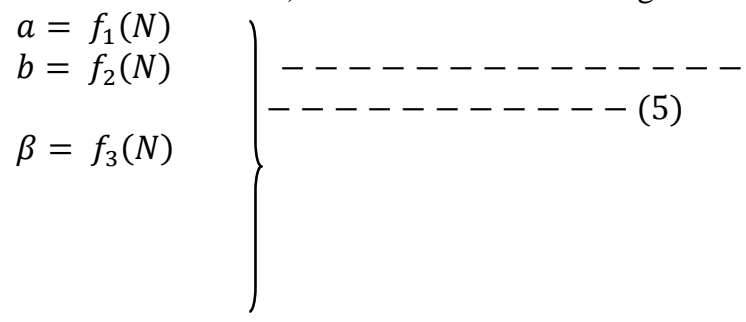

A line of best fit was obtained and the values obtained were substituted into the original exponential equation (i.e. equation 1) with the following results;

$a=3.64 C-68.47--------------$

$$
--------(6)
$$

$$
\begin{gathered}
b=6.22 \times 10^{-7} N-1.91 \times 10^{-3}------- \\
---------(7) \\
\beta=2.485-0.016 C----------- \\
----------(8)
\end{gathered}
$$

With the substitution of the values in equation (4) and (5) into the original exponential equation we have this result;

$$
\begin{gathered}
B=f_{1}(c) t^{f_{3}(c)} e^{f_{2}(N) t^{2}}----------- \\
---------(9 a)
\end{gathered}
$$

Using the values in equation 6,7 and 8 to do substitution in the exponential equation (i.e eqn. 1) we obtain;

$B$

$=(3.64 C$

$-68.47) t^{(2.485-0.016 c)} e^{\left(6.22 \times 10^{-7} N-1.91 \times 10^{-3}\right) t^{2}}$

$------(9 b)$

\subsection{Analysis of results}

Following the analysis of the results obtained, attempt was made to establish between the model constant and the concentration of crude oil as well as the amount of nutrients added. The result shows that the constant ' $a$ ' is linearly related to crude concentration in a linear proportionally trend. Also, the constant ' $b$ ' is directly related to the nutrient added. An increase in ' $b$ ' produces a corresponding increase in $N$. the constant ' $\beta$ ' possesses inverse proportionality with ' $C$ ' (i.e. concentration of crude oil). As the constant $\beta$ increases, the concentration ' $C$ ' decreases and vice versa.

When the values determined were put into the model,

\begin{tabular}{|c|c|c|}
\hline $\begin{array}{l}\text { Nutrients } \\
\text { added }\end{array}$ & $\begin{array}{ll}\text { Crude } & \text { oil } \\
\text { concentration }\end{array}$ & $\begin{array}{l}\text { Coefficient } \\
\text { correlation }\end{array}$ \\
\hline \multirow[t]{4}{*}{$\mathrm{Og} / \mathrm{L}$} & 25 & 0.984 \\
\hline & 50 & 0.982 \\
\hline & 75 & 0.983 \\
\hline & 100 & 0.983 \\
\hline \multirow[t]{2}{*}{$83 \mathrm{~g} / \mathrm{L}$} & 25 & 0.981 \\
\hline & 75 & 0.974 \\
\hline \multirow[t]{2}{*}{$125 \mathrm{~g} / \mathrm{L}$} & 25 & 0.994 \\
\hline & 50 & 0.988 \\
\hline $167 \mathrm{~g} / \mathrm{L}$ & 25 & 0.992 \\
\hline $417 \mathrm{gL}$ & 50 & 0.995 \\
\hline \multirow[t]{2}{*}{$520 \mathrm{~g} / \mathrm{L}$} & 25 & 0.991 \\
\hline & 50 & 0.998 \\
\hline
\end{tabular}
the bacterial or biomass number B was calculated and the results were compared with the measured data. Correlation between the calculated and measured data was determined and results are presented on Table 1 .

Table 1 Model performance

From the table of model performance, a maximum correlation coefficient of 0.998 was obtained with a 
Obi Lawrence E.

minimum of 0.974 and an average of 0.987 was obtained. The relationship existing between the

constants, concentration of crude oil and nutrients added are shown in subsequent Figure 1 to 7.

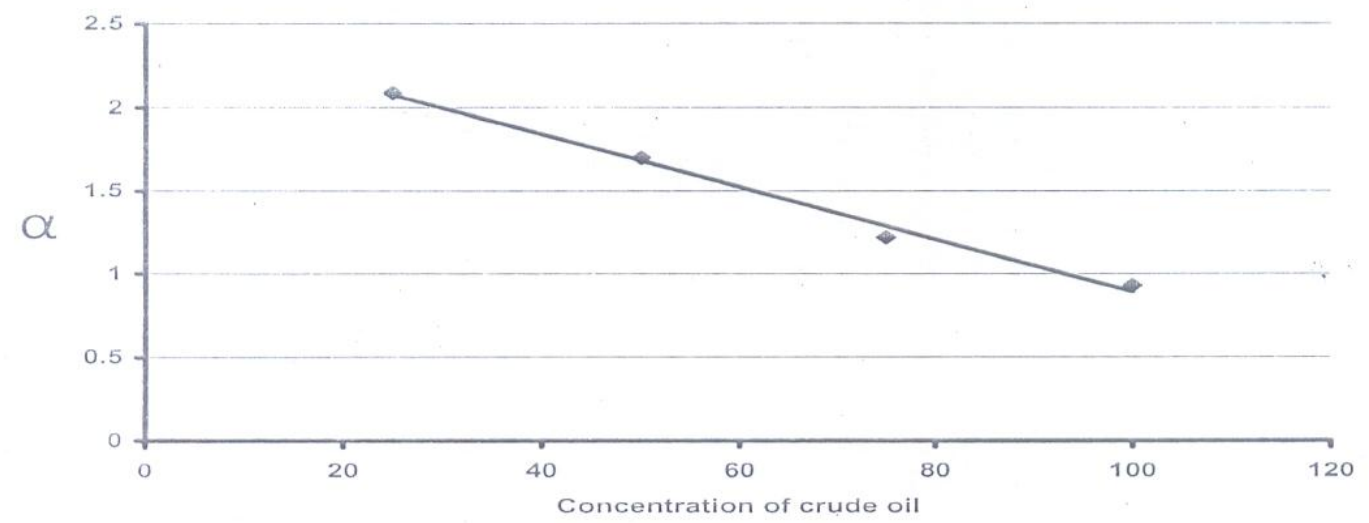

Figure 1 Relationship between Constant $(\alpha)$ and concentration of crude oil

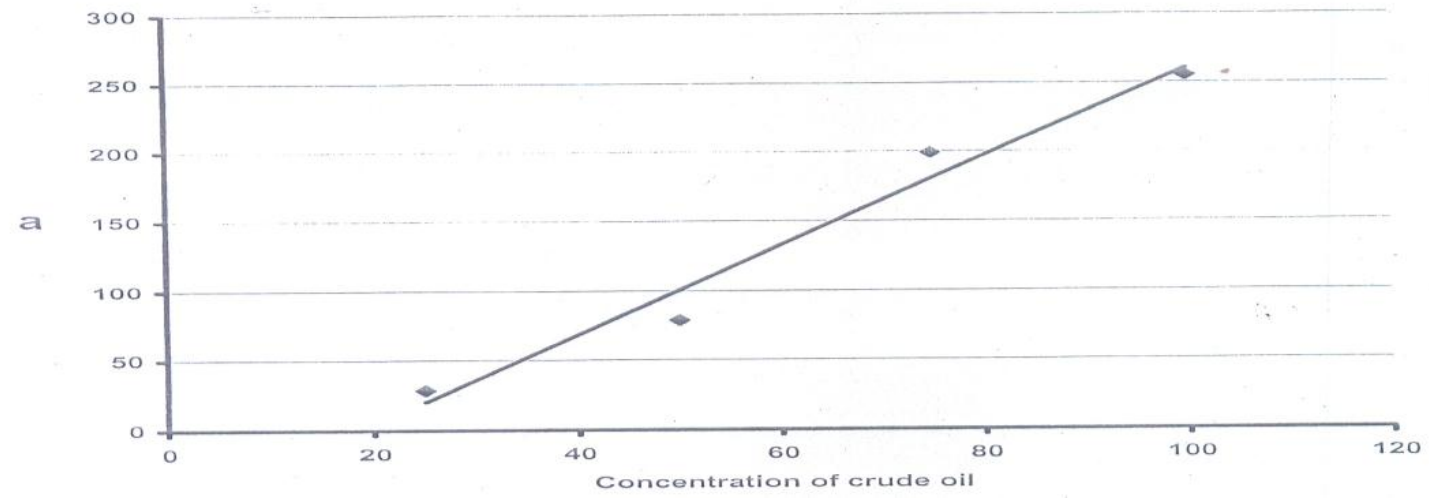

Figure 2 Relationship between constant a and concentration of crude oil

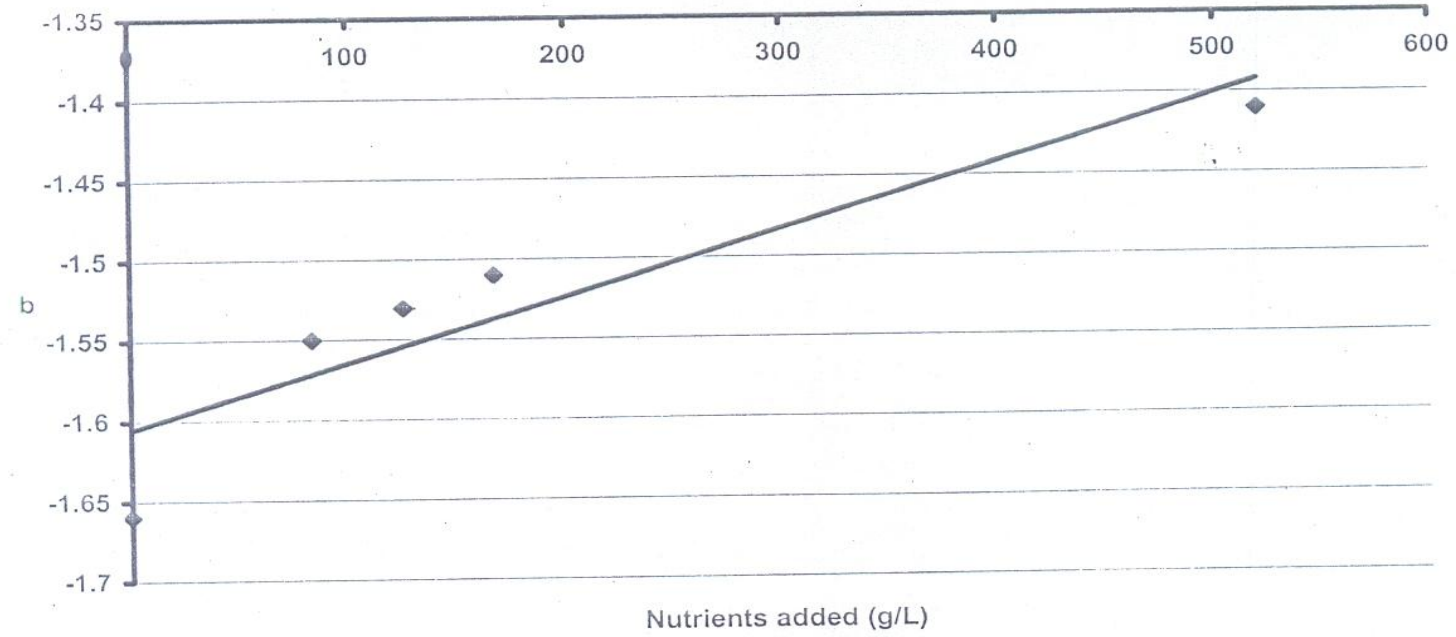

Figure 3 Relationship between constant $b$ and concentration of crude oil 
International Journal of Advanced Technology and Engineering Exploration, Vol 4(35)

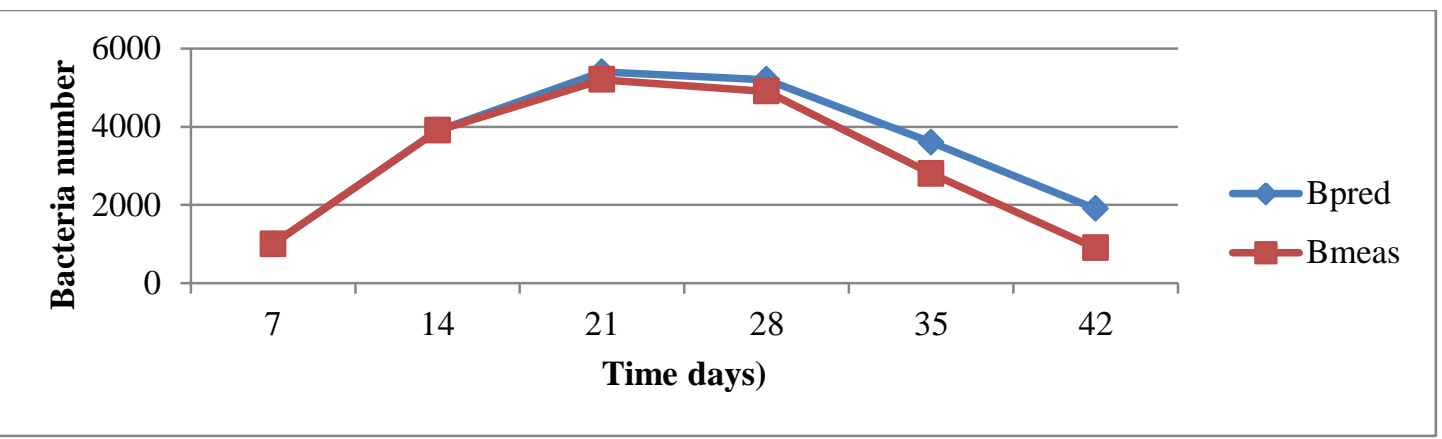

Figure 4 Variation of Biomass number with time at nutrient $=0 \mathrm{~g} / \mathrm{L}$ and conc. $=25$

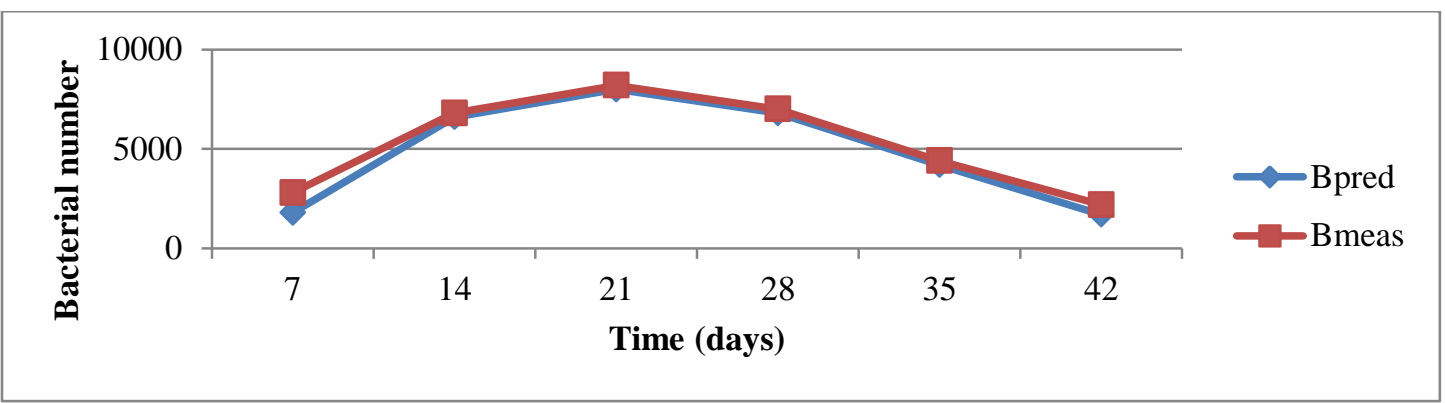

Figure 5 Variation of Biomass number with time at nutrient $=0 \mathrm{~g} / \mathrm{L}$ and conc. $=50$

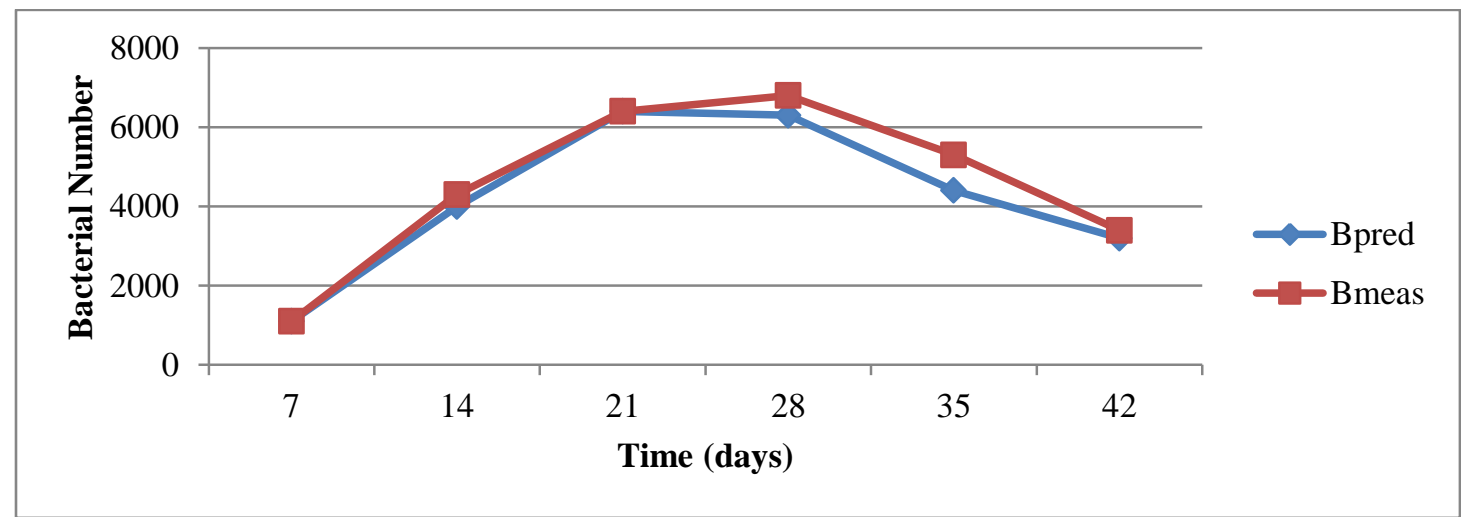

Figure 6 Variation of Biomass number with time at nutrient $=520 \mathrm{~g} / \mathrm{L}$ and conc. $=25$

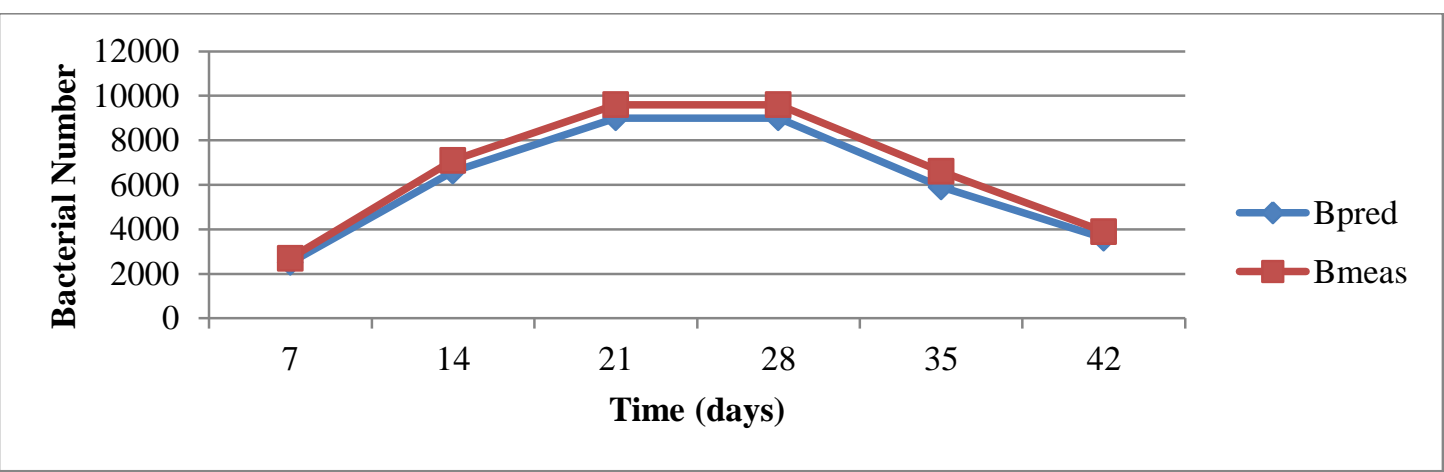

Figure 7 Variation of Biomass number with time at nutrient $=520 \mathrm{~g} / \mathrm{L}$ and conc. $=50$ 
Obi Lawrence E.

\section{Conclusion}

Crude oil polluted sites have become a great menace to oil producing areas of Nigeria and other parts of the world. This has motivated the development of a model which can make the clean-up operations of crude oil spillage affected areas to be faster with a greater precision. Bacterial growth or biomass number depends on several factors such as the concentration of crude oil, amount of nutrients added, time and temperature. In view of these factors, a predictive model was developed to determine the number of bacteria responsible for the rate of degradation of the crude oil polluted sites. With the result of this work, it was established that the concentration of crude oil and the nutrients added are critical with enormous implication on the bacterial growth. It is suggested that future works be undertaken on the rate of degradation the various types of crude oil to ascertain if they have different rates of degradation.

\section{Acknowledgment}

None.

\section{Conflicts of interest}

The author has no conflicts of interest to declare.

\section{References}

[1] Agunwamba JC. Waste engineering and management tools. Immaculate Publication Limited, Enugu; 2001.

[2] Agunwamba JC, Ezeogu L.I, Chukwu. Effects of nutrient, crude oil pseudomonas concentrations on fungal growth. International Journal of Environmental Issues. 2008.; 2(1): 132-42.

[3] Folaranmi F. Anger in, bayelsa over oil spillage. Dialy Sun Newspapers. 12 September 2017. pp. 25.

[4] Boufadel MC, Li H, Suidan MT, Venosa AD. Tracer studies in a laboratory beach subjected to waves. Journal of Environmental Engineering. 2007; 133(7):722-32.

[5] https://clu-in.org/download/remed/542f06013.pdf. Accessed 12 September 2017.

[6] Kogbara RB. Ranking agro-technical methods and environmental parameters in the biodegradation of petroleum-contaminated soils in Nigeria. Electronic Journal of Biotechnology. 2008; 11(1):113-25.
[7] Onyenjoro $\mathrm{CH}$. Modeling rate of degradation in grade oil pollution sites. M.Sc. Thesis, University of Nigeria, Nsukka, 2010.

[8] Osuji LC, Onojake CM. The Ebocha-8 oil spillage: II. Fate of associated heavy metals six months after. African Journal of Environmental Assessment and Management. 2004; 9:78-87.

[9] Venosa AD, Suidan MT, Wrenn BA, Strohmeier KL, Haines JR, Eberhart BL, et al. Bioremediation of an experimental oil spill on the shoreline of Delaware Bay. Environmental Science \& Technology. 1996; 30(5):1764-75.

[10] Zhu X, Venosa AD, Suidan MT, Lee K. Guidelines for the bioremediation of marine shorelines and freshwater wetlands. US Environmental Protection Agency. 2001.

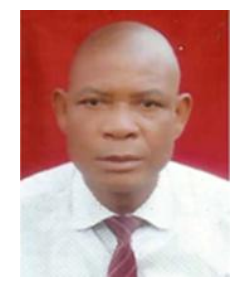

Dr. Obi Lawrence E. is a native of Ihioma in Orlu, Imo State Nigeria and he is a Senior Lecturer in the Department of Civil Engineering, Imo State University, Owerri. He holds a $\mathrm{Ph} . \mathrm{D}$ in Civil Engineering from the renowned Federal University of Technology, Owerri, Imo State, Nigeria. He is an experienced academic who has served as the Head of Civil Engineering Department and through his dint of hardwork and mental prowess facilitated the accreditation of his department by Council for the Regulation of Engineering in Nigeria and the Nigerian Universities Commission. He is a chartered engineer and belongs to many professional bodies which include Nigerian Society of Engineers, Nigerian Institution of Civil Engineers, Nigerian Institution of Water Resources Engineering, Nigerian Renewable Energy Society, etc. He is a Fellow of the Institute of the Industrial Administration of Nigeria. Engr. Dr .L.E. Obi has published extensively both in national and reputable international journals. He has earned such awards as the best H.O.D. Award for Civil Engineering, Eastern Merit Award for Excellence in Education, Distinguished Leadership Award, Golden General Secretary Award, etc He is currently the Chairman of International Conference in Engineering to be hosted by the Faculty of Engineering Imo State University, Owerri, Nigeria. His areas of interest in research include Optimization of Water Resources Engineering Systems, Modeling of Engineering Systems, Numerical Applications in Water Resources Development and Environmental Engineering.

Email: engrlawobi@yahoo.com 